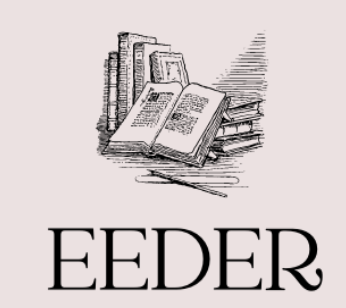

\title{
Koray ÜSTÜN*
}

\section{Süreli Yayınların Biyografik Türlerin Gelişimine Katkısı ve Bir Örnek: Mınak Efendi’nin Tercüme-i Hâli**}

The Contribution of Periodic To The Development of Biographic Genres

And A Example: Mınakyan’s Autobiography

ÖZ

\begin{abstract}
Türkçe süreli yayınlar yalnızca haber aktarma, fikir paylaşma, ihtisas bilgisi sunma ya da basıldığı çağın popüler meselelerini duyurma işlevlerini taşımamış; aynı zamanda edebi türlerin gelişimine de büyük ölçüde katkı sağlamıştır. Gazete aracllığıyla nesir dili doğmuş, yeni türler ilk örneklerini okurlarıyla buluşturmuştur. Yalnızca şiir, roman ya da öykü gibi başat türler değil anı, deneme, biyografi, otobiyografi gibi türlerin doğup gelişmesinde de süreli yayınlar rol üstlenmiştir. Bu türlerin Batılı bir forma dönüşmesi yine bu yayınlarla sağlanmıştır. Bu makalenin amacı, süreli yayınların biyografik türlerin gelişimine etkisini göstermektir. Bu amaç doğrultusunda biyografi türünün süreli yayınlardaki görünümüne örnek teşkil edecek yazılardan bahsedilmiş, bu yazıların ortak özelliklerine değinilmiş ve ardından Mardiros Mınakyan tarafından kaleme alınan "tercüme-i hâl” incelenmiştir. Osmanlı tiyatrosunun hem sahne önünde hem de rejisör ve sanat yönetmeni olarak sahne arkasındaki gelişimine katkı sunan Mınakyan'ın İkdâm'da yayımladığı otobiyografik ögeler taşıyan yazısı, yalnızca onun kişisel tarihine değil aynı zamanda Türk tiyatro tarihinin başlangıç yıllarına da ışık tutmaktadır.
\end{abstract}

Anahtar kelimeler: Süreli yayınlar, İkdâm, biyografi, otobiyografi, Mardiros Mınakyan

\section{ABSTRACT}

Turkish periodical publications have not only served the purpose of broadcasting news, sharing ideas, presenting expert knowledge or pronouncing the popular events of their age of publication but have also contributed to the development of literary genres significantly. Prose literature has been born by the hand of newspapers, and new genres have met with their audience. Periodical publications have served a role in developing not only major genres as poems, novels and stories but have also helped develop genres as memoirs, essays, biographies and autobiographies. The formation of these genres into western forms in Turkish literature have also been through periodicals. The aim of this article is to present the role of periodicals in developing biographical genres. For this purpose, writings that exemplify the biographical genres in periodicals and the common qualities of said writings have been discussed. Consequentially, as an example of this interaction, "Tercüme-i Hâl" by Mardiros Mirakyan has been discussed. This work of Mınakyan, who has helped develop Ottoman theatre in all roles of a director and art director and on the stage, published with the help of periodicals that has autobiographic tones, does not only illuminate his personal history but also the commencement years of Turkish theatre.

Keywords: Periodicals, İkdam, biography, autobiography, Mardiros Mınakyan

*Dr. Öğr. Üyesi, Hacettepe Üniversitesi, Edebiyat Fakültesi, Türk Dili ve Edebiyatı Bölümü korayustun@hacettepe.edu.tr ID ORCID: 0000-0003-1033-5966

${ }^{* *}$ Araştırma Makalesi, Geliş Tarihi: 10.11.2021 Kabul Tarihi: 15.12.2021 Yayın Tarihi: 30.12.2021

DOI: 10.31465/eeder.1021956

(Bu makale, yazar beyanına göre, TR DİZIN tarafından öngörülen “ETIKK KURUL ONAYI” gerektirmemektedir.) 


\section{GİRIŞ}

Türk edebiyatının "yeni”" devresinin başlatıldığı yılların Türk basınının doğuşu ile paralellik göstermesi şüphesiz tesadüf değil, bir zihniyet oluşumunun aksidir. Tanzimat yıllarının aydın kuşağı ile bu kuşağın yanı başında yetişen bir neslin ortaya koyduğu ürünler, benzer bir arayışın izlerini taşımakta, işlevsel ortaklıklar barındırmaktadır. Takvim-i Vakâyi ile başlayan kamuoyu oluşturma amacı, Yeni Türk edebiyatının ilk eserlerinde de kendini göstermekte ayrıca nazımdan nesre her türün örneği, içinde üretildiği çağın düşünsel arka planını somutlaştırmaktadır. Bu bağlamda basın-edebiyat ilişkisinin başlangıçtan itibaren çok sıkı biçimde sürdüğünü söylemek mümkündür ${ }^{1}$. Her iki türün gelişmesini sağlayan faillerin aynı kişiler olması da bu bağın kaçınılmazlığını göstermektedir. Başlangıçtaki zihniyet ortaklığı ve ortaya çıkış motivasyonlarındaki paralellik, her iki türün birbiriyle olan etkileşimini sürekli kılmış ve bu süreklilik, her iki sahayı da ciddi anlamda zenginleştirmiştir. Edebi türlerin varlığ bir dinamizm kazanan gazeteler, bu türlerin doğuşuna ve gelişimine öncülük etmiştir. "Nesir dilinin oluşmasına katk1, yeni türlerin denenmesi, yılların ilerlemesiyle üretimin artması ve her iki tarafin da halkı/halkın eğitimini dolayısıyla toplumsal kalkınmayı hareket noktası olarak belirlemesi; edebiyatın gazetenin gelişiminde gazetenin edebiyatın gelişiminde ne kadar etkili olduğunu gösteren unsurlardır" (Ergün Atbaş1, 2017: 93). Gazetelerini birer kürsüye, edebi eserlerini de dramatik bir eğitici sahneye dönüştüren devrin yazarları, bu bağlamda teorik ve pratik açıdan rol dağılımını yapmış gibidir. Düşünsel içerik, gazeteler aracıllğıyla halka ulaştırılırken bu düşüncelerin eyleme aksedişi edebi eserler aracılığıyla sağlanmıştır. Başta Namık Kemal ve Ahmet Midhat Efendi olmak üzere Tanzimat'ın izinde yetişen edebiyatçı ve gazeteci kimliği taşıyan tüm aydınların bu ortak zeminde buluştuklarını söylemek mümkündür.

Basın ve edebiyat sahalarında yeniliğin doğuşuna etki eden zihniyet ortaklığının yanında bu iki mecra, aynı zamanda birbirlerini süreklilik arz etme ve geniş bir kitleye ulaşma noktasında da etkilemiştir. Gazeteler, edebi eserler yayımlayarak onların daha geniş bir okur grubuna erişilmesini sağlamış, eserler de gazete içeriklerini önemli ölçüde zenginleştirmiştir. Şair Evlenmesi ile başlayan bu süreç, Tanzimat'tan Cumhuriyet'e sayısal açıdan artarak devam etmiştir. Gazete ve dergilerde pek çok çeviri ve telif roman tefrika edilmiş, öyküler yayımlanmış, şiirler basılmıştır. Şiir, roman, öykü gibi kurmaca türlerin yanı sıra musahabe başlığı altında deneme, sohbet, eleştiri türleri ile birlikte anı, mektup, biyografi (yaşamöyküsü) ve otobiyografi (özyaşamöyküsü) gibi kişinin tanıklıkları, yaşanmışlıkları ya da çeşitli kaynaklardan hareketle kaleme aldığı metinler de gazeteler aracılığıyla özgün bir kimlik kazanmışlardır. Bu türler arasında Türk edebiyatının en eski örneklerinden itibaren kendini gösteren biyografik türlerin varlı̆̆ 1 da dikkat çekicidir.

\section{Biyografik Türler ve Süreli Yayınlar}

Türk yazılı kültürünün en eski kaynakları kabul ettiğimiz yazıtlardan bugüne, -kişisel tanıklık ve yaşantılara dayanan tecrübeler ile yaşam öykülerini aktaran ya da kaynaklardan elde edilen verilerden hareketle bir kişinin yaşamına odaklanılarak kaleme alınan pek çok metin bulunmaktadır. "İnsanlıkla yaşıt bir bilim dalı olan biyografi, başlangıçta tarih içinde yer alırken zamanla bağımsız bir bilim dalı halinde gelişip serpilmiştir" (İsen, 2010: 3). Özellikle İslamiyet'in kabulü ile birlikte, yeni bir kültür dairesine dâhil olunmuş ve edebiyatımızda İslam kültüründe

${ }^{1}$ Detaylı bilgi için bkz. Çıkla, 2009. 
yaygın olan bu içerikteki yazıların sayısı artmıştır. Din büyükleri ile başlayıp zamanla farklı meslek erbabı için de kaleme alınan biyografiler, tezkirecilik faaliyetleri ile birlikte tarihten edebî olana doğru bir seyrin izlerini taşımaya başlamıştır ${ }^{2}$. Türk edebiyatında bireyin keşfedilişiyle çerçevesi daha da belirginleşen biyografiler, müstakil olarak varlığını güçlenerek göstermekle birlikte diğer edebi türleri de beslemiş; biyografik romanlar, öyküler, tiyatrolar kaleme alınmıştır.

Yüceltilen güncel ya da tarihî şahsiyetlerle birlikte yeni tanınan ve merak edilen kişiler üzerine de biyografiler yazılmış, bu eserlerle biyografi, popüler bir kimlik de kazanmaya başlamıştır. Biyografi türünün Tanzimat'tan II. Meşrutiyete kadarki örnekleri üzerine hazırladığı tezinde Akar, üç yüze yakın eser tespit etmiş, bu dönemde tezkireden modern biyografiye geçişin yavaş da olsa gerçekleştiğini söylemiştir. Çoğunluğu topluma bir rol model olarak sunulan tarihî ve dini öncü kişilerin yaşamöykülerinden oluşan bu dönemin eserlerinde didaktik unsurların ağırlıklı olduğunu tespit eden Akar, bu amaçla sade ve akıcı bir dilin kullanıldığını vurgulamıştır (2013). Süreli yayınların biyografi türünün gelişimine etkisi de telif kitapların yayımlandığı bu y1llarda belirginleşmeye başlamıştır. Özellikle günlük siyasi ve kültürel gündemde rol alan kişilerin yaşamları halk tarafından merak edilmiş ve basın, bu merakı gidermek amacıyla tarihî ve askeri kimliklerin yanında gündemdeki kişilerin biyografik bilgilerine de sayfalarında yer vermiştir.

XIX. yüzyllın son çeyreğinden itibaren yaşanan siyasal hareketliliklerin etkisiyle süreli yayınlarda, fikir içerikli yazıların yerini haberler almaya başlamıştır. Bu haberlerin yanı başındaki "Tercüme-i hâl" başlığı altında, gündemdeki siyasi ve askeri kimlikleriyle ön plana çıkan kişiler, bilim ve teknik sahalarında rol oynayan mucitler ve ortaya koydukları sanat eserleriyle gündeme gelen sanatçıların biyografileri yayımlanmıştır. Ayrıca çağın romantik duyarlılıklarının etkisiyle tarihi kişiliklerin yaşamları paylaşılırken realist ve natüralist eğilimlerle de bilim adamları biyografilerine yer verilmiştir.

Haber metinleriyle ilişkili kısa parçaların yanı sıra uzun biyografi tefrikalarına da gazetelerde rastlanılmaktadır. Sade ve anlaşılır bir gazete dili ile kaleme alınan bu metinler, bir yandan okurların genel kültür düzeylerini olgunlaştırırken öte yandan biyografi türünün gelişimine katkı sağlamıştır. Türk basın tarihi üzerine yapılan lisansüstü indeks çalışmalarından hareketle süreli yayınlarda biyografi türünün tuttuğu yere ilişkin olarak şu örnekleri vermek mümkündür: Dağarcık'ta Diyojen, Voltaire, İmam Fahrettin-i Razi; Tercüman-ı Hakikat'te Beşir Fuad, Tolstoy, Ömer Hayyam Bach, İmparator Wilhelm, Diderot, Edison, La Fontaine, Racine, Giordano, Demosthenes, Vergilius, Dante, Shakespeare (Bozpolat, 2013; Köseoğlu, 2014; Yayman, 2019); Tanin'de Kösem Sultan, Sarah Bernhardt, Ahmet Şuayb, Sabah'ta "Meşahir-i İslam", "Eâzım-1 Ümem”, "Sanayi-i Nefise", "Payitaht-Osmanlı Ressamları" üst başlıklarıyla aktarılan yaşamöyküleri ile Nuri Şeyda, Recaizade Mahmut Ekrem, Gorki, Vambery, Ebuzziya Tevfik, Rıza Tevfik, Selim Sırrı (Demirel, 2002; Yüksel, 2014; Özkan, 2019; Arduç, 2019; Yakuplar, 2019); Şura-yı Ümmet'te "Hayat-1 Meşâhir” üst başlığıyla yayımlanan yaşamöyküleri (Bedir, 2005) ve Peyam-ı Sabah'ta “Tanıdıklarım” başlığı altında Refik Halit'in kaleme aldığı portreler ile Sakıp Dede, Paul Aden, Edirneli Örfi, Anatole France, Ibsen, Dostoyevski, Nüzhet Nuri, Salebî, Örfi (Çetinkaya, 2019).

\footnotetext{
${ }^{2}$ Türk edebiyatındaki tezkire geleneği için detaylı bilgi için bkz. İsen, 2010; Kılıç, 2011.
} 
Herhangi bir tasnife tâbi tutulmaksızın yukarıda anılan kişiler, süreli yayınlarda biyografisi yayımlanan kişi kadrosunun farklı tipolojilerden geldiğinin bir göstergesi olmakla birlikte süreli yayınların dinamizmi içinde biyografilerin yerini de belirginleştirmektedir. Askerî ve siyasi zaferleriyle tarihi değiştiren ve dinî, millî ve edebî öncü kimlikleriyle çağını aşan kişiler hakkında yazılan biyografilerin dışında dönemin gündemi ile ilişkilendirilebilecek biyografilerin de süreli yayınlarda görünmesi, o devrin haber metinleri içinde biyografik bilginin de bir yer tuttuğunu göstermektedir. Dönemin iç ve dış siyasetine dair haberlerin yanı başında siyasi ve askeri aktörlerin biyografilerine kısa da olsa yer verilmiştir. Ayrıca bir tartışmanın tarafı olması ya da yaşamını yitirmesi nedeniyle de sanat ve kültür insanlarının biyografik bilgileri okurla paylaşılmıştır.

Biyografilerine yer verilen kişiler, Osmanlı vatandaşları ile sınırlı değildir. Dünya tarihine iz bırakan pek çok ismin yaşam öyküsüne de süreli yayınlarda rastlamak mümkündür. Biyografilerin hacimleri, yazılış amaçlarına göre değişmekte; nekroloji olarak nitelendirilebilecek parçalar daha kısa iken tefrikalarla aktarılan biyografiler nispeten daha uzundur. Biyografilerde benimsenen üslupta görülen çeşitlilik de dikkat çekicidir. Yazılarda ansiklopedik bir bilgi aktarımı görüldüğü gibi yazarının olumlu ya da olumsuz değerlendirmelerini de içeren eleştirel tonda yazılmış biyografiler bulunmaktadır. Mizah gazetelerindeki biyografilerde ise ironik ve alaycı bir üslup görülmektedir.

Süreli yayınlarda yer bulan biyografik metinler arasında yazarın kendi yaşamöyküsünü kendi kaleminden sunduğu metinlere de rastlanılmaktadır. Bu bağlamda diğer edebî türlerin doğuşunda olduğu gibi otobiyografinin ${ }^{3}$ doğuşunda da süreli yayınların rolünden bahsetmek mümkündür. Bu bağlamda tespit edilen en dikkat çekici üç metin, Şemsettin Sami'nin Ahmet İhsan arac1lığıyla Servet-i Fünûn'un 275. sayısında yayımladığ 1 tercüme-i hâli ${ }^{4}$, Refik Halid'in Peyâm-ı Sabah'ın 812 ve 815. sayılarında basılan "Kendime Dair I-II" başlıklı yazıları ve İkdâm'ın 2692 ve 2693. sayılarındaki “Mınak Efendi'nin Tercüme-i Hâli I-II” adındaki parçalardır.

\section{Mardiros Minakyan Üzerine}

Mardiros Mınakyan (1839-1920), Osmanlı tiyatrosuna uzun yıllar emek vermiş, hem reji hem de oyunculuk yaparak tiyatronun gelişimine büyük katkılar sunmuş bir sanatçıdır. Yaşamını sahne üzerine kuran ve ömrü boyunca tiyatroya aşkla bağlanan Mınakyan, İstanbul Hasköy'de doğup büyümüştür. Öğrencilik yıllarının ardından ilk kez on sekiz yaşında sahneye çıkmış, devrin siyasal ve toplumsal şartları el verdiği ölçüde tiyatro ile iç içe bir yaşam sürmüştür. 1862'de Naum Tiyatrosunda oynanan Aristothéme'deki rolüyle tiyatro yaşamı profesyonel olarak başlayan Mınakyan, İzmir'deki Vasprogan Tiyatrosu'nda Ermenice ve Türkçe oyunlar oynamıştır. Kayseri'ye öğretmen olarak gitmesiyle birlikte ${ }^{5}$ tiyatroya ara vermek zorunda kalan sanatçı, İstanbul'a döndügünde Balyan Agop tarafından kurulan Magakyan Tiyatrosundan gelen teklifi kabul ederek bu kumpanyaya dâhil olmuştur. Magakyan'ın hedeflediği kazancı sağlamasının

\footnotetext{
${ }^{3}$ Türk edebiyatında biyografi (yaşamöyküsü) ve otobiyografi (özyaşamöyküsü) türünün tarihsel gelişimi ile ilgili olarak bkz. Yazıc1, 2006; Gökalp Alpaslan, 2016.

${ }^{4}$ Ahmet İhsan'ın Servet-i Fünûn'un 6 Haziran 1312 tarihli 275. sayısında yayımlanan "Şemsettin Sami Bey" başlıklı yazısı, Yüksel Topaloğlu tarafından bir inceleme ile birlikte yayımlanmıştır. Bkz. Topaloğlu, 2012.

${ }^{5}$ Mınakyan'ın Kayseri'ye gidişinin aslî nedeni olarak istibdat devrine muhalif olması görülmektedir. Sanatçının devrin sosyal ve kültürel yaşamı içindeki muhalif tutumuna dair bkz. Yalçın, 2002; Demiryürek, 2009; Öztürk, 2019.
} 
ardından kumpanyayı dağıtması üzerine buradaki bütün oyuncularla birlikte o da Vartovyan Kumpanyası'na geçmiştir. Ancak Gedikpaşa Tiyatrosunda Vatan yahut Silistre'nin sahnelenmesi sonrasında yaşananlardan onlar da paylarını almış ve İstanbul'dan uzaklaştırılmışlardır. OsmanlıRus Savaşı'nin ertesinde Edirne'ye geçen oyuncular arasında Mınakyan da vardır. Edirne'deki temsillerinin ardından İstanbul'a dönen Mınakyan, daha sonra Tiflis'e geçerek faaliyetlerini sürdürmüştür. Titiz çalışması ile bilinen sanatçı, burada sıklıkla taltif edilmiş, takdir toplamıştır. İstanbul'a dönünce yeniden Vartovyan Kumpanyasına giren Mınakyan, Abdülhamid tarafından saraya alınarak kumpanya müdürlüğüne getirilmiştir. İdari desteğin de etkisiyle Beyoğlu'ndaki Kroasan Tiyatrosunu ayağa kaldırarak Benliyan ile birlikte burada operetler sahneye koyan

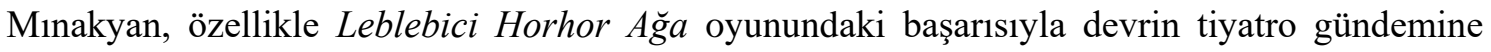
damga vurmuştur.

Güllü Agop'un mirasını yaşatarak 1885'te kurduğu Osmanlı Dram Kumpanyası onun Türk tiyatrosunun gelişime sağladığı önemli katkılardandır. Bu çatı altında iki yüz elliden fazla oyun sahnelenmiştir. Mınakyan, bir süre Mısır'a giderek oyunlarını orada da sahnelemiş, beğeni toplamış, maddi olarak desteklenmiştir. İstanbul'a ekibiyle birlikte dönüşünün ardından halkın beğeni ve isteklerini gözeten popüler oyunlar yazan, çeviren ve sahneleyen Mınakyan, bu süre zarfında meslektaşlarının mesleki hırsları ve kıskançlıkları dolayısıyla kimi zaman yalnız kalmış kimi zaman farklı işbirliklerine girmiştir.

Meşrutiyet'in ilan edilmesinin ardından tiyatro dünyasında çokseslilik görülmeye başlanmış, Mınakyan da bu dönemde kurulan pek çok kumpanyaya destek olmuştur. Tasfiye-yi Ahlâk Kumpanyası, Benliyan ve Küçük topluluklarının birleşmesiyle kurulan yeni tiyatro, Donanma Cemiyeti Heyet-i Temsiliyesi gibi kuruluşlarda da oyunculuk ve sanat yönetmenliği yapan Mınakyan, Darülbedayi'de öğretmenlik yapmış, tatbikat sahnesini yönetmiş̧ir. Mınakyan'ın 50. sanat yılı onuruna bir jübile düzenlenmiş, törende Maarif Nişanı ile taltif edilmiş ayrıca onun adına Türkçe-Ermenice bir albüm neşredilmiştir ${ }^{6}$. 1916' da sahne hayatını noktalayan Mınakyan, 18 Kasım 1920'de vefat etmiş, cenazesi büyük bir kalabalık eşliğinde Şişli'deki Ermeni Mezarlığına defnedilmiştir. (Tuncor, 1988; And, 1958).

Mınakyan, kimi zaman oyuncu olarak sahnede kimi zaman yazar, rejisör ya da sanat yönetmeni olarak sahne arkasında tiyatro için çalışmış; Osmanlı tiyatrosunun doğuşu ve gelişimine bizzat katkıda bulunmuştur. Dramdan komediye geniş bir oyun dağarcığı bulunan sanatçı, dönemi içinde de takdir edilmiş; Türk tiyatrosunun Frédérick Lemaître'i olarak anılmış, Temâş̧̂ิ'nın açtığı ankette Türk tiyatrosuna iz bırakan birinci isim seçilmiştir (And, 1958, 1972). Devrin çeşitli gazete ve el ilanlarından hareketle Mınakyan tiyatrolarınca oynanan oyun dağarcı̆̆ını tespit eden Metin And'ın ortaya koyduğu bilgilerden hareketle, Mınakyan'ın durmaksızın tiyatro için çalıştığını söylemek mümkündür (And, 1958, 1966). Dönem içerisinde hem rolleri hem de eserleriyle bıraktığı izler, devrin yazarlarınca kaleme alınan çeşitli yazılara aksetmiştir. Örneğin, Sermet Muhtar Alus, onun sahnede değişmeyen "müşfik, aile ocağına

\footnotetext{
${ }^{6}$ Arşok Garayan Matbaası tarafından yayımlanan bu albümde Mınakyan’ın yaşamı detaylı olarak Türkçe ve Ermenice olarak yayımlanmış ayrıca sanatçının on dokuz fotoğrafına yer verilmiştir. "Tercüme-i Hâl, Sanatkâr-1 Şehir Mardiros Mınakyan" adlı albümün Osmanlıca kapağında başlık altında "Efendi-i mûmâileyh tiyatroculuk meslek ve sanatına duhulünün ellinci sene-i devriyesinin şerefine icra kılınan jübile şenliği münasebetiyle” bilgisi yer almaktadır. Atatürk Kitaplığı Arşivinde bulunan kitap üzerine Cüneyd Okay’ın da bir tanıtma yazısı mevcuttur. Bkz. Okay, 1997.
} 
muhabbetli, çoluğuna çocuğuna düşkün bir baba" rolünü canlandırdığını söylerken ${ }^{7}(1950$, s. 105) Safvet Nezihi, Osmanlı Dram Tiyatrosunun ahlak, eğiticilik ve öğreticilik bakımından uygun olduğunu ifade etmiştir (1318, akt. And 1972, s. 124).

\section{Mınakyan'ın Kaleminden Tercüme-i Hâli}

19. yüzyılın ikinci yarısından II. Meşrutiyet senelerine dek tiyatroyla iç içe bir yaşam süren ve tiyatronun gelişimine büyük katkı sağlayan Mınakyan'ın yaşamöyküsü yalnızca onun kişisel tarihini değil aynı zamanda Osmanlı tiyatrosunun geçirdiği merhaleleri göstermesi bakımından da dikkate değerdir. Bu bağlamda bizzat kendi kaleminden çıkan yaşamöyküsünün değeri daha da artmaktadır.

Kevork Pamukciyan bu yazının, Sarkis Tütüncüyan'ın "Şarasan” mahlasıyla Ermenice hazırlayıp 1915'te İstanbul'da yayımladığı Türkiyeli Ermeni sahne sanatkârları hakkındaki çalışmasında basıldığını, bu kitabın Mınakyan'la ilgili bölümlerinin Nişan Beşiktaşlıyan'ın Taderakan Temker (Tiyatro Simaları) adlı kitapta yer aldığını söyleyerek nasıl yazıldığına dair şu bilgiyi aktarmaktadır:

"Müellif, bu otobiyografiyi 1901 yılı kasım ayında bazı dostlarının ısrarı üzerine kaleme aldığını ve 1872 yılına kadarki zamanı ihtiva ettiğini kaydettiği halde, kaynağını maalesef bildirmemektedir. $\mathrm{Bu}$ tercüme-i hâlin Türk tiyatro tarihi ile uğraşanlara meçhul kaldığını tahmin ederek Türkçeye çevirmeyi faydalı bulduk" (1968, s.32).

Pamukciyan'ın Ermenice kopyasından çevirerek yayımladığı bu metin, ilk olarak İkdam'ın 19 Kânunuevvel 1901 (8 Ramazan 1319/6 Kânunuevvel 1317) ve 20 Kânunuevvel 1901 (9 Ramazan 1319/7 Kânunuevvel 1317) tarihli 2692 ve 2693. say1larında "Minak Efendi'nin Tercüme-i Hâli I" ve "Mınak Efendi’nin Tercüme-i Hâli II" başlıklarıyla Türkçe yayımlanmıştır. $\mathrm{Bu}$ yazılarda Mınakyan; çocukluğu, gençliği, eğitimi, mesleki yaşamı, ailesi ve tiyatroya olan bağ l1lı̆̆ını dile getirmiştir.

Ansiklopedik bir bilgi aktarımından ziyade yazısında, geldiği noktada yokluklarla nasıl mücadele edip ne gibi zorluklar yaşadığını ve tiyatroya olan tutkusunun nasıl bir süreçten geçtiğini anlatan Mınakyan, samimi bir üslubu benimsemiştir.

Çocukluk yıllarının günlük yaşamına dair anımsamalarıyla yazısına başlayan Mınakyan, okul çağlarında maddi olanaksızlıklarla büyüdüğünü, başarılı bir öğrenci olduğunu ve hocaları tarafından takdir edildiğini anlatmış; anılarında yer tutan okul müdürü Toros Zorayan'ın yaşamındaki etkisine değinmiştir. Diğer öğrencilerin artıklarıyla karnını doyuracak kadar fakirlik çeken Mınakyan, hocası Zorayan'ın desteğini görmüş, on üç yaşından itibaren okulu bırakıp çalışmak zorunda kaldığını ancak yine Zorayan'ın yardımlarıyla okula döndüğünü minnetle ifade etmiştir. Devrin günlük yaşamına dair bilgileri de içeren bu satırların ardından Ermeni okullarında öğretmenlik yaptığı günleri ve bugünlerde ilk sahne tecrübelerini gerçekleştirdiğini anlatan Mınakyan, sahneye olan sevgisini fark etmesi üzerine "muallimliğin yükünden kurtularak" aktörlüğe geçtiğini söyler. Mınakyan'ın dönemin Ermeni oyuncularından gördüğü desteği, onlarla kurduğu yol arkadaşlığını, katıldığ1 kumpanyaları ve kimi ortaklıklarının nasıl sonlandığını anlattı̆̆ 1 satırlar tiyatro tarihinin bir dönemine de 1şık tutmaktadır. Sanatçının

\footnotetext{
${ }^{7}$ Sermet Muhtar Alus, hem gazete yazılarında hem de romanlarında, Osmanlı tiyatrosunu tanıklıklara dayanarak anlatmıştır. Alus, anlatılarında Mınakyan'dan da sıklıkla bahsetmiştir. Bu konu üzerine detaylı araştırma için bkz. Öztürk, 2019.
} 
Kayseri günleri ve yolculuğundaki tanıklıkları ise Anadolu'nun sosyal yaşamına dair dikkate değer izlenimlerdir.

Kayseri'deki öğretmenlik yıllarının ardından İstanbul'a dönüşü ve İstanbul'daki tiyatro âlemine vakit kaybetmeden dâhil oluşu Mınakyan'ın bu alana olan bağlılığını gösteren parçadaki önemli işaretlerdendir. Eşinin İstanbul'a dönüş amacını sorduğu ve kendisinin buna verdiği yanıtı aktardığı satırlar, sanatçının aile hayatına ilişkin fikir vermektedir. Bu cümleler aynı zamanda Mınakyan'ın samimi üslubunun bir kanıtı olarak görülmelidir. Üzerinden geçen kırk yıla yakın bir zamana rağmen tiyatroya dair isimleri, mekânları ve tiyatro için fedakârlıklarını detaylarıyla veren sanatçının kendi kaleminden yaşamı, Osmanlı Dram Kumpanyasının kuruluşuyla son bulmaktadır. Şüphesiz, aradaki otuz yıl da benzer fedakârlıklar, çabalar ve heyecanlarla geçmiştir. Mınakyan'ın yaşamöyküsünün devamını yazıp yazmadığı bilinmemekle birlikte yapılan taramalarda herhangi bir metne rastlanılmamıştır.

\section{Sonuç}

Süreli yayınlar, yalnızca roman, öykü, şiir gibi başat türlerin gelişimine değil aynı zamanda kişilerin yaşam öykülerinden doğan sohbet, anı, biyografi ve otobiyografi gibi türlerin olgunlaşmasında da etki etmiş̧tir. Gerek yazılı dilin oluşması gerekse bu metinlerin basılarak hedef kitlelerine ulaşması bağlamında somutlaştırılacak bu etki, gelenekte var olan kişisel anlatıların daha da bireysel bir çizgiye yerleşmesini ve böylelikle Batılı örneklerine form açısından yakınlaşmasını sağlamıştır. Bu durum, hem tarih bilimi içindeki biyografi çalışmalarına hem de edebî bir tür olarak biyografi ve otobiyografinin gelişmesine süreli yayınların rolünü göstermektedir. Tarihi, askeri, kültürel vb. rolleri nedeniyle yaşamları merak edilen kişilerin hayatındaki önemli noktaları muhataplarıyla buluşturan süreli yayınlarda bahsi geçen kişilerin yetişme ortamı, eğitimleri, bulundukları konumlar ve başarıları "tercüme-i hâl" başlığı altında bir haberle ilişkilendirerek ya da müstakil tefrikalar halinde yayımlanmıştır. Yazıların bazıları imzalı iken bazılarında yazar bilgisi bulunmamaktadır. Bu noktada kendi yaşam öykülerini kendi kalemlerinden çıkaran kişilerin yazıları da dikkat çekicidir. Osmanlı tiyatrosunun önemli isimlerinden Mardiros Minakyan da otobiyografisi yayımlanan isimlerdendir. İkdam gazetesinin 2692 ve 2693. sayılarında yayımlanan yazılarda Mınakyan; içinde yetiştiği sosyal şartlarla birlikte çocukluğunu, tiyatroya nasıl başladığını, öğretmenlik günlerini, tiyatroya yeniden dönüşünde kimlerle işbirliği kurduğunu anlatmıştır. Bu yazılar, önemli bir tiyatro adamı olan Mınakyan'ın biyografisine katkı sunmakla birlikte Osmanlı'nın son döneminde kültür sanat ortamına dair fikir vermektedir.

\section{Kaynaklar}

Akar, Gül Ayşe (2013). Tanzimat'tan II. Meşrutiyete Türk Edebiyatında Biyografi. Yüksek Lisans Tezi. İstanbul Üniversitesi.

Alus, Sermet Muhtar (1950). Minakyan'ın Osmanlı Tiyatrosu. Resimli Tarih Mecmuası, 3: 104 106.

And, Metin (1958). Mınakyan ve Tiyatrolarının Oyun Dağarcığı. Dost, 3:16 - 20.

And, Metin (1972). Meşrutiyet Döneminde Türk Tiyatrosu 1908-1923. İstanbul: Türkiye İş Bankası Kültür Yayınları.

And, Metin (1966). Mınakyan ve Tiyatrosunun Oyun Dağarcığı. Forum, 18 (284): 16 - 17. 
And, Metin (1966). Minakyan ve Tiyatrosunun Oyun Dağarcığı. Forum, 18 (285): 16 - 17.

Arduç, Gökay (2019). Sabah Gazetesi (8664-9393 Sayllar Inceleme ve Seçilmiş Metinler). Yüksek Lisans Tezi. Niğde Ömer Halisdemir Üniversitesi.

Bedir, İsmail (2005). Şurâ-yı Ümmet Gazetesinin (170-220) ve (140-1/140-122) Sayllarının Sistematik Indeksi-Incelemesi- Seçilmiş Yazıların Çevirisi. Yüksek Lisans Tezi. İstanbul Üniversitesi.

Bozpolat, Sedef (2013). Tercüman-ı Hakikat Gazetesi (2001-2500. Sayılar) Inceleme ve Seçilmiş Metinler. Yüksek Lisans Tezi. Cumhuriyet Üniversitesi.

Çetinkaya, Saliha (2019). Peyâm-ı Sabah Gazetesinde Edebî Faaliyet. Yüksek Lisans Tezi. İstanbul Üniversitesi.

Çıkla, Selçuk (2009). Tanzimat'tan Günümüze Gazete-Edebiyat İlişkisi. Türkbilig, 18: 34-63.

Demirel, Mecit (2002). Sabah Gazetesindeki Dil ve Edebiyat Yazılarının İncelenmesi ve Şiir Metinleri. Yüksek Lisans Tezi. İstanbul Üniversitesi.

Demiryürek, Meral (2009). II. Meşrutiyet Devrinde Ermeniler Üzerine Üç Piyes. Modern Türklük Araştırmaları Dergisi, 6 (1): 107-127.

Ergün Atbaş1, Nurtaç (2017). Türk Gazeteciliğinin Yeni Edebiyatın Doğuşuna Etkisi (1860-1876). Doktora Tezi. Hacettepe Üniversitesi.

Gökalp Alpaslan, Gonca (2016). Özyaşamöyküsünde Yazarın Yeniden Doğuşu. Ankara: Ürün Yayınları.

İsen, Mustafa (2010). Tezkireden Biyografiye. İstanbul: Kap1 Yayınları.

Kılıç, Filiz (2011). Klasik Türk Edebiyatının Peşinden. Ankara: Grafiker Yayınları.

Köseoğlu, Hatice (2014). Tercüman-ı Hakikat Gazetesi (3001- 3500. Sayllar) Inceleme ve Seçilmiş Metinler. Yüksek Lisans Tezi. Sivas Cumhuriyet Üniversitesi.

[Mardiros Mınakyan] (1901). Mınak Efendi’nin Tercüme-i Hâli II. İkdam, 2693: 2-3.

[Mardiros Mınakyan] (1901). Mınak Efendi'nin Tercüme-i Hâli. İkdam, 2692: 2.

Okay, Cüneyd. Mınakyan Efendi (Mınakyan Efendi"nin Ellinci Sene-i Devriyesi Yadigârı Adlı Eseri Üzerine). Toplumsal Tarih, 7(41): 62 - 64.

Özkan, Ayşegül Neslihan (2019). Sabah Gazetesi (1898-1900) (İnceleme ve Seçilmiş Metinler, 2921-3650). Yüksek Lisans Tezi. Niğde Ömer Halisdemir Üniversitesi.

Öztürk, Yakup (2019). Sermet Muhtar Alus ve Türk Tiyatrosu. Dil ve Edebiyat Araştırmalarl, 20: $105-143$.

Pamukciyan, Kevork. Kendi Kalemiyle Mardiros Minakyan. Hayat Tarih Mecmuası, 2(10): 32 34.

Topaloğlu, Yüksel (2012). Kendi Kaleminden Şemsettin Sami’nin İlk Tercüme-i Hâli. Trakya Üniversitesi Edebiyat Fakültesi Dergisi, 2 (4): 81-94.

Tuncor, Ferit Ragip. Mardiros Minakyan (1839-1920). Yeni Defne, 7(74): 12 - 19.

Üstün, Koray (2017). İkdam Gazetesinde Edebi Faaliyetler (1894-1913). Türkbilig, 34: 135-154.

Yakuplar, Gökhan (2019). Sabah Gazetesi (10124-10821. Sayılar Inceleme ve Seçilmiş Metinler). Yüksek Lisans Tezi. Niğde Ömer Halisdemir Üniversitesi. 
Yalçın, Alemdar (2002). II. Meşrutiyette Tiyatro Edebiyatı Tarihi. Ankara: Akçağ Yay.

Yayman, İsmail Göktuğ (2019). Tercüman-I Hakikat Gazetesi (2501-3000. Sayllar) İnceleme ve Seçilmiş Metinler. Yüksek Lisans Tezi. Sivas Cumhuriyet Üniversitesi.

Yazıc1, Nermin (2006). Türk Edebiyatında Otobiyografi. Türkbilig, 11: 189-217.

Yüksel, Levent (2014). Sabah Gazetesi Üzerine Bir İnceleme (1902-1903 / 4381 - 5096). Yüksek Lisans Tezi. Niğde Üniversitesi.

Çatışma beyanı: Makalenin yazarı, bu çalışma ile ilgili taraf olabilecek herhangi bir kişi ya da finansal ilişkisi bulunmadığını dolayısıyla herhangi bir çıkar çatışmasının olmadığını beyan eder.

Destek ve teşekkür: Çalışmada herhangi bir kurum ya da kuruluştan destek alınmamıştır.

\section{Ek:}

\section{Mınak Efendi'nin Tercüme-i Hali 1}

Şâyan-1 dikkat artistimiz Mınak Efendi, kendi tercüme-i hâlini hikâyesinde diyor ki:

\section{Minak Efendi}

Hasköy'de son derece fakir bir ailenin sulbünden dünyaya geldim. Orada taayyüş ettim, orada büyüdüm. Pederim terzi idi. Küçük yaşımda aileme bâr olmamak için sabahları mektebe gitmezden evvel pederimin dikmiş, hazırlamış olduğu pantolonların düğmelerini diker, akşamları, mektepten avdetimde evimiz için iktizâ eden suyu taşırdım. Mektepteki öğle yemeğim arkadaşlarımın sofralarında artan kırıntılardan ibaret idi ki bunu mektep hademesi toplar ve kendisinin sevmediği, hoşuna gitmediği şeyleri bana verirdi.

Sınıf arkadaşlarımın içinde terfi-i sınıf ederdim. Muallimlerin ezcümle o zaman mektebimizin müdürü bulunan müteveffâ Toros Efendi, beni pek çok severdi. Senede iki kat elbise ile mektep için iktizâ eden kitap, kâğıt vesairemi bu zat tedarik ederdi. Her yıl başında da bana güzel bir takvim yahut nefis bir resim ihdâ ederdi.

On üç yaşına girdiğim zaman validem fakir halimizden nâşi beni komşumuz olan bir değirmencinin yanına verdi. O günden itibaren her sabah sırtımda biraz kararmış bir camcı gömleği ve omzumda boş bir zembil olduğu halde Ayvansaray’da kâin dükkânımıza gider ve akşamları dolu zembili alarak ustamın hanesine götürerek abla tesmiye ettiğim zevcesine teslim ederdim. Bir ay kadar bu hizmetle istihdam edildim. Bir Pazar günü -mutat olduğum veçhile- kiliseye gittim fakat üst başımdan utandığım için içeriye girmeye cesaret edemeyerek dış kapıya yakın bir mahalde duruverdim. Bu sırada mektep müdürü Toros Efendi, beni gördü ve yanıma gelerek dedi ki:

- Mardik! Neredesin, mektebe niçin devam etmiyorsun, bu üst baş ne?

Mektep haricinde imrâr etmiş olduğum bir aylık sergüzeşt-i hayatımı kendisine naklettim. Sonra kolumdan tutarak beni doğruca kilise âzâlarının huzuruna götürdü. Orada dedi ki:

- Efendiler! Bu çocuk mektebimizin en zeki, en çalışkan bir şakirdi idi. Ne çare ki ebeveyni fakir hallerinden nâşi kendisini bir değirmenci yanına vermişler. Lütfen şu çocuğa muâvenet ediniz.

Müdürümüzün şu ifadesi üzerine kilise meclis azasından iki zat bana muâvenet, beni himâye edeceklerini kararlaştırdılar. Derhal pederimi meclise davet için adam gönderdiler. Pederim evde bulunmadığı için validem geldi. Evimize günde bir ekmek göndermek ve benim her nev'i ihtiyacım kendilerine ait olmak şartıyla beni mektebe göndereceklerini valideme teklif ettiler. Onun canına minnet! Validemin muvâfakatini istihsal ettikten sonra velilerim, Nikoli namında müstahdemlerinden biriyle beni Galata'ya hamama gönderdiler. Hamamda, baştan ayağa kadar hep yeni elbiselerle dışarı çıktım. Bir bohça 
derununda olan çamaşırlarımı da alarak doğruca velilerimin nezdine gittim ve arz-ı teşekkür zımnında ellerini öptükten sonra evimize avdet ettim.

O günden sonra tam beş sene müddetle mektepte çalıştım, yemeğim vakt-i zamanında geliyordu. Artık bir zengin çocuğu gibi yemek vaktinde daima fakir bir arkadaş bulur, yemeği beraber yerdik.

Beş sene sonra, velilerim, biri diğerine müteâkiben vefat ettiler. Mâmâfih ben o zamana kadar oldukça büyümüş ve mümkün mertebe iktisâb-1 mâlûmat etmiş olduğum cihetle artık kendi kendimi idare edebilirdim. Az vakit sonra mektebimizde muallim muavinliğine tayin olundum. Daha sonra Gedikpaşa ve Eyüp Mahalle Mekteplerinde îfâ-yı vazife ettim. Bir müddet bu surette geçinebildikten sonra Hasköy’de kâin Nersesyan nam mektepte ilm-i hesap muallimliğine davet olundum. Bu mektepte ara sira müteveffâ Çaprasdcıyan'ın rejisörlüğü altında tiyatro oyunları oynardık.

Bu zamanlarda idi ki mezkûr Nersesyan Mektebi’nin arka sokağında Hasköy Tiyatrosu namıyla bir tiyatro tesis ve küşat edildi.

\section{Mınak Efendi'nin Tercüme-i Hali 2}

Hasköy Tiyatrosunda ancak bir gece icrâ-yı sanat edilebildi. Zira Mösyö Naum tarafından Beyoğlu'nda Opera Tiyatrosu'nun tesis ve küşadı üzerine mezkûr tiyatro ihtiyar-1 ta'til etmişti.

Hasköy Tiyatrosunda aktörlükten Aşiyan Migakyan ve Acemyan Efendilerle maârife peydâ etmiştim ki bunlar bilâhare Beyoğlu'nda Mösyö Naum'un tiyatrosunda icrâ-yı sanat eyledikleri sırada ben de davet ederler idi. Opera Tiyatrosunda mevki-i temâşâya vaz-olunan Aristodem piyesinde ilk rolüm inattan hiç kimse bulunmamak hasebiyle Aristodem'in kızı Gesira'nın rolü idi.

Birkaç sene sonra yani 1859 sene-i miladiyyesinde Altunyan, Meryemkuli ve Hurdacıyan Efendilerin taht-1 idaresinde olarak bir tiyatro küşad edildi. İşte bu zamanlarda idi ki muallimlik mesleğini terkle aktörlüğe sülûk ettim.

Eski aktörlerden İtalyalı Mösyö Astyers müdürümüz, Afşiyof Mugakyan ve Acemyan Efendiler üstatlarımız olup Fasulyeciyan, Tıryans, Çıracı, Sedefciyan locası, Mirasiyan Efendilerle Arusyan ve hemşiresi Agavni Hanımlar hep arkadaş idik.

İki sene müddetle yazın nısf-ı maaş alarak oyunları meşk eder, kışın da tamamı maaşla mevki-i temâşâya vaz ederdik.

Terziyan, Tığlıyan Efendilerle telif ve tercümeleriyle bize muâvenette bulunurdu. İkinci sene evâhirinde tiyatromuz kapandı. O senenin kışında icrâ-yı sanat zımnında kumpanya ile İzmir'e gittik. İlk günleri iyi gitti, kazanıyorduk, gittikçe muvaffakiyeti kaybettik. Bu sırada aktörlerimizden T. Fasulyeciyan ile Matmazel Bayzar Papazyan yekdiğerini teehhül ettiler.

İzmir'den avdetimizde Hekimyan Sarobyan Efendi bir tiyatro istîcar ve bir müddet sonra Tıngrosyoman Efendi de kendisine iştirak etti. Karakaşyan Efendi ile Araksi ve Agavni (Şimdi Binemeciyan Hanım) Hanımlar o sırada bize iştirak etmişlerdi. Bir sene sonra Manasik Tostil tiyatromuza bir Fransız opera kumpanyası geldi. Biz de bittabi açıkta kalarak yine muallimliğe karar verdik.

Bu sıralarda Kayseri Mektebi için bir muallim ve bir muallimeye lüzum görünmüştü. Beni tavsiye etmişler, ben de bu vazifeyi reddetmedim. Üsküdar'dan da bir muallime buldum ki bilahare Madam Mınak oldu.

Samsun tarikiyle Kayseri’ye giderken yolda Çakmak tesmiye olunan bir Ermeni köyüne tesadüf ettik. Buranın ahâlisi bizim muallimlik vazifesiyle Kayseri’ye gitmekte olduğumuzu haber almış olmakla okumuş adamlar hakkında öteden beri besledikleri bir fikre binâen "bu adam da zevcesi de okumuştur" diyerek bir sıtması için elime bir miktar pamuk tutuşturur, diğeri zevcemi bir hasta üzerine okumaya davet ederdi.

Zevcemin ilk okuduğu hasta vefat etti. Kulağı sağır, dilsiz bir kız üzerine de okudu... Bu kızın dili bilâhare tesadüfen açılmış olmakla avdetimizde hediyeten pek çok pide, bulgur ve cevizli alabildik.

Kayseri'de dört sene müddetle muallimlik vazifesi ifa eyledikten sonra, Dersaadet'e avdet etmeye karar verdim. Zira gazetelerde mevki-i icraya vaz' olunacağı mu'lin bulunan tiyatro ilanlarını okudukça yüreğim hopluyordu. 
1873 sene-yi miladiyyesinde, kış üstü faiz olarak kazandığım üç nefer çocukla beraber Dersaadet'e avdet ettim. Yolda zevcem İstanbul'da muallim mi yoksa aktör mü olacağımı soruyordu... Hiç aktör olacağımı söyler miyim? Fakat buraya ayak atar atmaz köprü üzerinde Kalemciyan Efendi’yi gördüm, tesâdüf bu ya! Bu zat bir kumpanya teşkil etmiş ve benim geleceğimi haber almış olmakla beni beklemekte olduğunu haber verdi. Ertesi gün doğruca Ortaköy’e gittim. Orada Migakyan, Atamyan, Sisak, Tiryans, Matosyan Efendilerle Madam Hıraçyan, Matmazel Asdğik ve hemşiresi Siranuş'la sair bazı zevatı buldum ki kemal-i muvaffakiyetle icrâ-yı mahâret etmekte idiler.

Magakyan Efendi'nin idaresinde bulunan kumpanyamız beş ay müddet icrâ-yı sanat eyledi. Müdürümüz cümlemizin menfaatine ayrı ayrı oyunlar mevki-i temâşâya vaz' edip bizi memnun ettikten sonra bir de kendi menfaatine bir oyun tertip etti.

Bundan sonra kumpanyamız, oyunlarına nihayet vermiş olmakla ben ve Tıryans başka bir tiyatro kumpanyası idaresine geçtik.

1880 tarihinde bir müddet Atamyan ve Karakaşyan Efendilerle oynadım, bir sene sonra Sancakcıyan Efendi ile Mari Nevaret Hanım bize iştirak ettiler. Bir müddet sonra “Osmanlı Dram Kumpanyası” teşkil etti ki elyevm idare etmekteyim.

Alâ-kaderi'l-iktidar piyesler intihap ederek bizzat tercüme ediyor ve ettiriyordum. Kumpanyamda bulunan zevatla hoş geçinmek birinci emelimdir. Bunun için birine güldüğüm zaman diğerine ağlarım. Birine hizmet ettiğim sırada diğerine ruy-1 muhabbet gösteririm. Hâsılı elimden geldiği kadar kâh birini kâh diğerini memnun etmeye çalışırım. Söylenilen sözlere lüzumundan fazla ehemmiyet veririm. Kumpanyama dâhil olmak için birçok rıza ve minnetten sonra namus ve haysiyetimi lekedâr etmek isteyenlerin hallerine acirım.

İşte tercüme-i hâlim, işte hayatım.

M. Minak 